Indonesian Journal of Legality of Law
e-ISSN : 2477-197X
https://postgraduate.universitasbosowa.ac.id/

\title{
ANALISIS HUKUM PENYIDIKAN TERHADAP PELAKU TINDAK PIDANA KEKERASAN DALAM RUMAH TANGGA (STUDI KASUS POLRES BONE)
}

\author{
Legal Analysis Of Investigation Against Criminal Acts Of Domestic Violence (Case Study in Bone) \\ Ferdinansyah Tahir ${ }^{1}$, Marwan Mas², Yulia A. Hasan ${ }^{2}$ \\ ${ }^{1}$ Kepolisian Resot Kabupaten Bone \\ ${ }^{2}$ Program Studi Ilmu Hukum Program Pascasarjana Universitas Bosowa \\ Email: ferdinansyahtahir93@gmail.com
}

Diterima: 10 September 2021/Disetujui: 20 Desember 2021

\begin{abstract}
ABSTRAK
Tujuan penelitian ini adalah untuk mengetahui dan menganalisis proses penyidikan terhadap pelaku tindak pidana kekerasan dalam rumah tangga di Polres Bone, dan untuk mengetahui dan menganalisis faktor-faktor penyebab terjadinya kekerasan dalam rumah tangga di Polres Bone. Penelitian ini dilakukan di Polres Bone khususnya Unit Perlindungan Perempuan dan Anak. Tipe penelitian yang digunakan dalam penelitian ini adalah tipe normatif. Teknik pengumpulan data yaitu dengan cara mempelajari beberapa literatur baik buku, artikel maupun materi kulia yang diproleh. Bentuk interview yaitu teknik pengumpulan data dengan cara melakukan wawancara serta meminta data. Hasil penelitian ini menunjukkan bahwa proses penyidikan terhadap pelaku tindak pidana kekerasan dalam rumah tangga di Polrestabes Makassar sudah sesuai prosedur yang berlaku, adapun faktor terjadinya kekerasan dalam rumah tangga karena beberapa faktor seperti kultur/ kebudayaan, ekonomi dan faktor keturunan.
\end{abstract}

Kata Kunci: Analisis Hukum, Kekerasan, Rumah Tangga

\begin{abstract}
The purpose of this study was to identify and analyze the process of investigating the perpetrators of domestic violence at the Bone Police, and to identify and analyze the factors causing domestic violence at the Bone Police. This research was conducted at the Bone Police, especially the Women and Children Protection Unit. The type of research used in this study is the normative type. The data collection technique is by studying several literatures, both books, articles and lecture materials obtained. The form of interview is a data collection technique by conducting interviews and asking for data. The results of this study indicate that the process of investigating the perpetrators of criminal acts of domestic violence at the Bone Polrestabes is in accordance with applicable procedures, while the factors for the occurrence of domestic violence are due to several factors such as culture, economy and heredity.
\end{abstract}

Keywords: Legal Analysis, Criminals of Domestic Violence

This work is licensed under Creative Commons Attribution License 4.0 CC-BY International license

\section{PENDAHULUAN}

Sejak dilahirkan kedunia, manusia sudah mempunyai kecenderungan untuk hidup bersama dengan manusia lainnya dalam suatu pergaulan hidup. Hidup bersama antara seorang laki-laki dan seorang perempuan melalui ikatan perkawinan untuk membentuk sebuah rumah tangga (keluarga). Perkawinan merupakan suatu ikatan yang melahirkan keluarga sebagai salah satu unsur dalam kehidupan bermasyarakat. Sebagaimana diatur dalam Pasal 1 Undang-Undang RI Nomor 1 Tahun 1974 tentang Perkawinan bahwa perkawinan ialah ikatan lahir bathin antara seorang pria dengan seorang wanita sebagai suami isteri dengan tujuan membentuk keluarga (rumah tangga) yang bahagia dan kekal berdasarkan Ketuhanan Yang Maha Esa.
Setiap pasangan yang telah menikah tentunya menginginkan kehidupan yang bahagia, tentram, damai, dan sejahtera. Untuk mewujudkan keutuhan dan kerukunan rumah tangga sangat diperlukan adanya pengendalian diri dan kualitas perilaku yang baik dari setiap anggota keluarga. Perkawinan adalah suatu perbuatan hukum, sehingga konsekuensi bagi setiap perbuatan hukum yang sah adalah menimbulkan akibat hukum berupa hak dan kewajiban bagi kedua belah pihak suami istri atau juga pihak lain. Seperti yang diatur dalam Pasal 33 Undang-Undang RI Nomor 1 Tahun 1974 tentang Perkawinan bahwa suami isteri wajib saling cinta mencintai, hormat-menghormati, setia dan memberi bantuan lahir bathin yang satu kepada yang lain. Jika melihat uraian di atas, maka pada prinsipnya rumah tangga merupakan tempat berlindung bagi seluruh anggota keluarga. 
Namun kenyataannya, keluarga bisa menjadi tempat penderitaan dan penyiksaan karena permasalahan rumah tangga yang terkadang diselesaikan dengan cara-cara yang kurang beretika, salah satunya dengan tindakan kekerasan. Kekerasan yang terjadi dalam rumah tangga mengandung sesuatu yang spesifik atau khusus.

Kekhususan terletak pada hubungan antara pelaku dan korban, yaitu hubungan kekeluargaan atau hubungan pekerjaan (majikan-pembantu rumah tangga). Selain itu, locus delicti pada kekerasan dalam rumah tangga lebih spesifik, yaitu di dalam rumah, di mana pelaku dan korban bertempat tinggal. Dalam tindak pidana yang lain, locus delicti bisa di mana saja, di semua tempat. Berbagai macam penyebab dan faktor dijadikan alasan sehingga kekerasan dalam rumah tangga bisa terjadi. Namun, yang menarik perhatian publik adalah kekerasan yang menimpa kaum perempuan (istri). Apalagi jika kekerasan tersebut terjadi dalam ruang lingkup rumah tangga. Seringkali tindak kekerasan ini disebut hidden crime (kekerasan yang tersembunyi).

Disebut demikian karena baik pelaku dan korban berusaha untuk merahasiakan perbuatan tersebut dari pandangan publik. Kadang juga disebut domestic violence (kekerasan domestik), karena terjadinya kekerasan di ranah domestik Kekerasan dalam rumah tangga sebenarnya bukan hal yang baru. Terlebih lagi persoalan kekerasan dalam rumah tangga (KDRT) menyangkut juga persoalan hak asasi manusia. Adanya kekerasan dalam rumah tangga (KDRT) dapat disebabkan tidak adanya penghargaan dalam memenuhi hak-hak dasar manusia, diantaranya hak dan kewajiban yang sama di dalam hukum. Tindak kekerasan dalam rumah tangga yang dilakukan oleh seorang suami terhadap istrinya atau sebaliknya sering dianggap sebagai hal yang biasa terjadi dalam sebuah keluarga. Biasanya jika terjadi kekerasan dalam rumah tangga, baik pelaku maupun korban menutupi hal tersebut. Karena akan dianggap sebagai aib bagi keluarga mereka. Padahal tindakan kekerasan merupakan suatu perbuatan yang melanggar hukum dan tentu saja pelakunya dapat dikenakan sanksi pidana yang telah diatur dalam UU Nomor 23 Tahun 2004 tentang Penghapusan Kekerasan dalam Rumah Tangga.

Dalam kenyataannya sangatlah sulit untuk mengukur secara tepat luasnya kekerasan terhadap perempuan, karena ini berarti harus memasuki wilayah peka kehidupan perempuan, yang mana perempuan sendiri enggan membicarakannya. Padahal kita ketahui bahwa setiap bentuk kekerasan dalam rumah tangga telah diatur dalam Undang-undang RI Nomor 23 Tahun 2004 tentang Penghapusan Kekerasan dalam Rumah Tangga (UU PKDRT) dan tentu saja melanggar hak-hak yang telah diatur dalam Pasal 28 huruf G ayat 1 UUD NRI 1945 bahwa: Setiap orang berhak atas perlindungan diri pribadi, keluarga, kehormatan, martabat, dan harta benda yang di bawah kekuasaannya, serta berhak atas rasa aman dan perlindungan dari ancaman ketakutan untuk berbuat atau tidak berbuat sesuatu yang merupakan hak asasi.

Salah satu kasus kekerasan dalam rumah tangga (KDRT) yang terjadi di BONE yakni seorang istri berinisial AI (20) melaporkan kasus kekerasan dalam rumah tangga (KDRT) ke Polres Bone pada tanggal 20 Maret 2019. Kasus KDRT dilakukan oleh suami korban berinisial AW (22). Sumber: Htpps:data/kekerasan/dalam/rumahtangga/.diakses oktober 2020
Kasus kekerasan dalam rumah tangga (KDRT) yang terjadi pada korban AI berupa kekerasan fisik yang berulangulang dilakukan oleh pelaku (AW) yang merupakan suami korban. Masih adanya kasus kekerasan dalam rumah tangga (KDRT) yang terjadi di sekitar kita dikhawatirkan memberikan dampak yang sangat besar bagi korban maupun anak mereka. Sehingga diperlukan penanganan yang serius dalam penyelesaian kasus kekerasan dalam rumah tangga (KDRT) tersebut. Dalam pelaporan kasus kekerasan dalam rumah tangga (KDRT) di kepolisian, khususnya di Polres Bone, kasus yang dilaporkan mengalami peningkatan dari tahun 2018-2019. Fakta ini dapat terlihat dari data laporan kekerasan dalam rumah tangga (KDRT) di wilayah hukum Kepolisian Bone dua tahun terakhir yakni 2018 - 2019 kasus, tahun 2018 sebanyak 15 kasus, dan selanjutnya pada tahun 2019 terjadi kenaikan yang sangat signifikan menjadi 23 kasus. (Sumber Data Unit PPA Polres Bone Tanggal 12 Oktober 2020)

Dari data tersebut, dapat dilihat bahwa ada peningkatan kasus kekerasan dalam rumah tangga (KDRT) di Kabupaten Bone. Adapun penyebab meningkatnya laporan kasus kekerasan dalam rumah tangga (KDRT) di kabupaten Bone disebabkan oleh faktor hukum atau undang-undang, faktor penegak hukum, faktor sarana atau fasilitas, dan faktor masyarakat. Kemudian, faktor penyebab seseorang melakukan tindak kekerasan dalam rumah tangga (KDRT) di kota Bone yakni faktor ekonomi dan faktor perilaku.

\section{METODE}

Penelitian ini adalah penelitian hukum normatif yaitu penelitian yang menggunakan pendekatan peraturan perundang-undangan dan regulasi yang berkaitan dengan isu hukum yang diteliti, dengan cara menelaah peraturan perundang-undangan yang berkaitan dengan penelitian. Dalam penelitian ini ada dua data yang di gunakan yakni: Data Primer dan Sekunder . Data Primer, yaitu data yang di peroleh dari sumber langsung melalui wawancara dengan pihak yang terkait yang sudah ditentukan, sedangkan data sekunder adalah data yang diproleh berdasarkan hasil telaah dan sejumlah peraturan perundang undangan, keputusan keputusan bahkan laporan, buku, jurnal, dan dokumen pendukung lainnya. Pengumpulan data dilakukan dengan cara wawancara langsung oleh pihak-pihak yang terkait yaitu dengan Kanit PPA Polres Bone dan Penyidik.

\section{HASIL DAN PEMBAHASAN}

\subsection{Analisis Hukum Penyidikan Terhadap Kekerasan Rumah Tangga}

Apabila kita melihat pada Undang-Undang No 23 tahun 2004 tentang pemberantasan tindak pidana kekerasan dalan rumah tangga, dalam pasal 10 bahwa : korban berhak mendapatkan perlindungan dari pihak keluarga, kepolisian ,kejaksaan, pengadilan, advokad, lembaga sosial, atau pihak lainnya baik sementara maupun berdasarkan penetapan perintah perlindungan dari pengadilan, namun dalam realitasnya adanya keterlibatan Pusat Pelayanan Terpadu Pemberdayaan Perempuan dan Anak (P2TP2A).

Kekerasan dalam rumah tangga yang dilakukan terhadap pasangan terkadang menjadi permasalahan yang tidak pernah diangkat kepermukaan. Meskipun kesadaran terhadap kekerasan terhadap pasangan berlangsung setiap saat 
fenomena KDRT diidentikkan dengan sifat permasalahan yang privat. Dari pandangan tersebut kekerasan terlihat sebagai tanggung jawab pribadi dan korban sebagai seorang yang bertanggung jawab dalam memperbaiki situasi yang sebenarnya didikte oleh norma-norma sosial . Dapat pula dilihat dari laporan-laporan kasus kekerasan disetiap tahun selalu ada laporan kekerasan dalam rumah tangga dan meningkatnya laporan kasus KDRT di kepolisian dengan berbagai macam jenis peristiwa yang dilakukan pelaku kepada korban. Suami dan istri didalam keluarga seharusnya saling mengayomi bahterah rumah tangga hingga menjadi keluarga yang harmonis, tetapi fakta yang terjadi salah satu dari anggota keluarga melakukan perbuatan menyimpang yang merugikan anggota keluarga lain dengan melakukan tindakan kekerasan. sehingga membuat korban menjadi merasa tersakiti tersakiti dan menimbulkan trauma pada dirinya. berikut:

Adapun data kekerasan dalam rumah tangga sebagai

Tabel 1.

Kekesaran Rumah Tangga

\begin{tabular}{|c|c|c|c|}
\hline No & Tahun & Jumlah & Penyelesaian \\
\hline 1 & 2018 & 15 & $\begin{array}{l}5 \text { laporan P21 dan } 10 \\
\text { Restoratif Justive }\end{array}$ \\
\hline 2 & 2019 & 23 & $\begin{array}{l}10 \text { Laporan P21 dan } 13 \\
\text { Restoratif Justive }\end{array}$ \\
\hline 3 & 2020 & 25 & $\begin{array}{l}10 \text { Laporan P21 dan } 15 \\
\text { Restoratif Justive }\end{array}$ \\
\hline
\end{tabular}

Sumber: Unit PPA Polres Bone Tahun 2021

Berdasarkan hasil penelitian yang penulis lakukan di Polres Bone ada beberapa kasus Kekerasan rumah tangga pada tahun 2018 yakni 15 laporan, namun dalam 15 laporan hanya 5 laporan yang dilimpahkan ke kejaksaan, 10 lainnya dilesaikan dengan cara kekeluargaan. Sama hal pada tahun 2019 dan 2020 dimana pada umumnya laporan kekerasan dalam rumah tangga cara penyelesaiannya yaitu Restoratif Justive. Berdasarkan pada tabel diatas bahwa adanya peningkatan kasus dari tahun 2018 ke tahun 2019 menurut penulis pekerjaan dan penghasilan bukan lah suatu jaminan terjadi kekerasan dalam rumah tangga karena salah satu faktornya adalah faktor keturunan (anak) , dimana korban melakukan laporan yang menjelaskan bahwa telah di aniyayah oleh suaminya karena sudah bertahun - tahun menikah akan tetapi belum di karunai momongan (anak). Namun selain dari itu ternyata Perempuan korban KDRT sangat jarang melaporkan suaminya ke polisi dengan berbagai alasan. Pertama, perempuan korban KDRT memiliki ketergantungan secara ekonomi dengan suami atau dengan kata lain tidak bekerja, sehingga apabila suami masuk penjara maka tidak ada lagi yang dapat membiayai kebutuhan rumah tangga dan sekolah anakanaknya. Kedua, perempuan korban KDRT lebih mempertimbangkan status di masyarakat karena adanya tanggapan negatif dari masyarakat terhadap perempuan yang berstatus janda dan juga perempuan korban KDRT menjaga perasaan anak-anaknya karena biar bagaimanapun suaminya adalah ayah dari anak-anaknya.

Pada tahun 2020 adanya peningkatan signifikan kasus kekerasan dalam rumah tangga yang faktor untamnya adalah perselingkuhan. Berdasarkan hasil wawancara penulis terhadap salah satu korban Cayah ${ }^{1}$ dimana dia telah dianiyaa oleh suaminya karena mendapati pesan singkat di handpone suaminya yang diduga keras adalah selingkuhan dari suaminya, sehingga Cayah mempertanyakan maksud dari pesan singkat tersebut akan tetapi suaminya marah dan emosi sehingga Cayah di aniyayah dengan cara di tampar pipi kiri nya dan di tendang perutnya sehingga mengakibatkan Cayah mengalami lebam di pipi kirinya dan mengalami keram di perutnya. Menurut analisis penulis bahwa bukan hanya faktor ekonomi , faktor keturunan akan tetapi faktor kesetiaan juga menjadi penyebab terjadinya kekerasan dalam rumah tangga.

\section{Aparat / Penegak Hukum Sendiri}

Berdasarkan hasil wawancara dengan Kanit PPA Polres Bone Muh. Tuo Latif, ${ }^{2}$ ia mengatakan bahwa yang memiliki kewenangan dalam penanganan kasus kekerasan dalam rumah tangga adalah Unit PPA dimana unit PPA Polres Bone memiliki beberapa personil diantaranya 5 laki-laki dan 3 perempuan. Tugas pokok sebagai Kanit yaitu mengawasi proses penanganan perkara yang ditangani oleh Unit PPA, dan memastikan agar proses penanganan berjalan dengan lancar lanjut Muh. Tuo selaku kanit PPA Polres Bone. Selain dari itu Untuk menyelengarakan pelayanan dan perlindungan terhadap korban KDRT, pemerintah, masyarakat atau lembaga sosial dapat bekerja sama dalam mendampingi korban. Kepolisian wajib memberikan keterangan kepada korban tentang hak korban untuk mendapat pelayanan dan pendampingan. Pendampingan korban dapat dilakukan oleh relawan pendamping, advokat, pekerja sosial, tenaga kesehatan, pembimbing rohani, dalam setiap proses pemeriksaan di kepolisian sampai dengan proses persidangan. Mengenai kewajiban dari pendamping korban kekerasan dalam rumah tangga (KDRT ) dapat dilihat di dalam Pasal 21 sampai dengan Pasal 25 Undang-Undang Penghapusan Kekerasan Dalam Rumah Tangga (PKDRT).

Setelah pelaporan dilaksanakan, dalam jangka waktu 1x24 jam, kepolisian wajib memberikan perlindungan sementara pada korban paling lama tujuh hari dan wajib meminta surat penetapan perintah perlindungan dari pengadilan. Dalam memberikan perlindungan sementara ini korban dapat didampingi oleh tenga kesehatan, pekerja sosial, relawan pendamping Lembaga Swadaya Masyarakat Perempuan (LSM Perempuan), advokat dan/atau pembimbing rohani. Dalam kasus ini penulis akan paparkan tahapan penyidikan yang dilakukan oleh penyidik PPA Polres Bone adalah sebagai berikut:

a. Gelar Perkara

Gelar Perkara merupakan penentuan hasil kesepakatan untuk peningkatan status laporan tahap penyelidikan ke penyidikan dan penentuan tersangka.

b. Peningkatan tahap penyelidikan ke tahap penyidikan Dalam hal ini Penyelidikan merupakan serangkaian tindakan yang dilakukan oleh PPA Polres Bone untuk mengumpul bukti valid bahwa telah terjadi tindak pidana kekerasan dalam rumah tangga, setelah tindakan tersebut mendapatkan bukti-bukti maka proses hukum akan ditingkatkan menjadi Penyidikan, berdasarkan pengetahuan penulis bahwa penyidikan merupakan serangkaian tindakan yang dilakukan oleh penyidik untuk memeriksa saksi-saksi dan menetapkan terlapor sebagai tersangka.

c. Pemeriksaan saksi-saksi 
Saksi-saksi dihadirkan oleh PPA Polres Bone guna untuk memproleh keterangan yang ia dengar, melihat, mengetahui dan mengalaminya sendiri.

d. Penetapan Tersangka

Dimana pihak kepolisian dalam hal ini penyidik melakukan pemeriksaan terhadap terduga tersangka agar mendapatkan titik terang suatu tindak pidana yang diduga telah dilakukannya.

Penyidikan, penuntutan, dan pemeriksaan di pengadilan dilaksanakan menurut ketentuan hukum acara pidana yang berlaku, kecuali ditentukan lain oleh Undang-Undang Penghapusan Kekerasan Dalam Rumah Tangga (PKDRT). Dalam proses ini korban hanya berhubungan dengan penyidik (polisi) pada saat proses Berita Acara Pemeriksaan (BAP), serta berhubungan dengan jaksa dan hakim pada saat pemeriksaan di pengadilan. Bahwa yang diperiksa pertama kali dalam proses persidangan adalah saksi korban KDRT dan untuk selanjutnya korban tidak diwajibkan untuk hadir di dalam persidangan.

Sebaiknya keluarga korban atau pendamping korban dapat hadir dalam setiap persidangan untuk memantau proses persidangan yang terjadi agar hakim, dalam memutus perkara, memperhatikan hak-hak korban. Dalam mempersiapkan korban menghadapi proses persidangan di pengadilan, korban atau keluarga korban dapat meminta bantuan kepada psikolog dan atau lembaga bantuan hukum/lembaga swadaya masyarakat yang khusus menangani kasus kekerasan terhadap perempuan dan anak.

\section{Pelaku}

Berdasarkan keterangan pelaku ia mengatakan ${ }^{3}$ bahwa ia merasa cemburu karena mendapati isterinya jalan dengan laki-laki lain menuju makassar, menurut pengamatan penulis bahwa pelaku tersebut tidak dapat mengontrol emosi sehingga terjadi lah kekerasan dalam rumah tangga yang mengakibatkan korban luka pada bagian telinga. Selain dari itu minimnya pengetahuan pelaku terkait dengan UndangUndang No 23 tahun 2004 tentang penghapusan kekerasan dalam rumah tangga. Padahal dalam Undang-Undang tersebut sudah menjelaskan Ancaman Pidana minimal 5 tahun dan maksimal 10tahun, dalam hal ini kejahatan kekerasan dalam rumah tangga tidak lah dapat berakhir dan memberikan efek jerah pada pelaku. Dalam kasus ini penulis berpendapat bahwa sebaiknya sebagai isteri seharusnya memiliki sifat terbuka terhadap suami sehingga tidak terjadi kasus serupa, dalam artian si istri memiliki kewajiban meminta izin terhadap suami ketika ingin berpergian sehingga tidak terjadinya kesalahfahaman yang mengakibatkan kekerasan.

\section{Masyarakat}

Berdasarkan hasil wawancara dengan Ms.. X salah satu masyarakat ${ }^{4}$ ia menyampaikan bahwa "kekerasan dalam rumah tangga terjadi karena keegoisan kedua bela pihak, kadang suami marah isteri juga ikut marah sehingga hal ini memicu pertengkaran yang berakibatkan adanya kekerasan dalam rumah tangga, tapi toh sebenarnya semua bersumber dari ekonomi ji lanjut Ms X. Berdasarkan pendapat penulis bahwa kekerasan dalam rumah tangga terjadi karena kurangnya sumber pendapatan sehingga hal ini lah yang membuat antara kedua bela pihak sering bertengkar yang berakibatkan terjadinya kekerasan dalam rumah tangga". Dan sebagai kepala keluarga seharusnya lebih giat mencari pekerjaan untuk memenuhi kebutuhan keluarga, serta tidak memilih-milih pekerjaan nya, sehingga dapat memenuhi kebutuhan keluarganya dan terhindar pula dari percekcokan antara suami istri yang kemudian mengakibatkan suami tidak dapat mengontrol emosinya dan memukul sang isteri, penulis juga beranggapan bahwa suami seharusnya lebih bisa mengalah terhadap isteri, karena pada hakikatnya isteri adalah wajib di lindungi bukan di kerasi dan ditindas.

\subsection{Faktor Terjadinya Kekerasan Dalam Rumah Tangga}

Kasus kekerasan rumah tangga di Kabupaten Bone terus saja meningkat, hal ini mengakibatkan beberapa faktor.

Kultur, ekonomi dan anak, adapun hasil wawancara penulis terhadap pihak yang terkait adalah sebagai berikut:

1. Kultur

Berdasarkan wawancara yang dilakukan pada Penyidik Asrtri Isnaini Safitri ia menyampaikan bahwa ${ }^{5}$ faktor ekonomi bukan lah merupakan faktor utama terjadinya kekerasan dalam rumah tangga, karena rumah tangga yang ekonominya baik juga sering mengalami kekerasan dalam rumah tangga, namun punca terjadinya kekerasan dalam rumah tangga karena faktor kultur hegomoni, sehingga salah satu solusi kekerasan dalam rumah tangga adalah hilangkan semua penyebabnya seperti penindasan, ketidakadilan, diskriminasi dan lain-lain, karena pada prinsipnya manusia di ciptakan sama, tidak ada perbedaan antara perempuan dan laki-laki (setara).

2. Ekonomi

Berdasarkan kasus yang penulis tangani bahwa pada umumnya kekerasan dalam rumah tangga terjadi karena faktor ekonomi, hal ini bermula apabila suami tidak memenuhi kebutuhan isteri sebagaimana mestinya, sehingga hal ini memicu rasa sakit hati pada istrii yang berakibatkan istri memaki maki suami seperti laki-laki sialan, macilaka, binatang dan lain-lainnya.

3. Anak/keturunan

Berdasarkan laporan adanya kekerasan dalam rumah tangga di Unit PPA Polrestabes Makassar yang menjadi faktor kekerasan adalah anak/keturunan, hal ini di karena sulitnya mendapatkan keturunan, sehingga antara suami dan isteri saling menyalahkan satu sama lain, hal ini lah yang mengakibatkan terjadinya kekerasan dalam rumah tangga. Menurut pendapat penulis bahwa persoalan keturunan dalam rumah tangga merupakan suatu anugerah yang diberikan oleh Tuhan, sehingga dalam rumah tangga tidak dapat saling menyalahi apabila belum diberikan keturunan, yang bisa dilakukan adalah berusaha dan berdoa.

Berdasarkan wawancara pada pelaku ${ }^{6}$ ia menyampaikan bahwa mereka sudah sering melakukan pengobatan medis maupun non medis agar isterinya bisa hamil, namun hal itu sering saja tidak berhasil, tiga tahun pernikahan belum diberikan momongan, hal ini lah yang sering membuat sepasang suami isteri tersebut berselisih faham sehingga terjadi lah kekerasan fisik terhadap isteri. Selain dari itu kedua pihak sering saling menyalahkan bahkan mengungkit prilaku pasangan dimasa lalu, setelah 3 tahun pernikahan tersebut, sang isteri tidak lagi ingin berobat medis maupun non medis, hal ini juga memicu kemarahan suami sehingga terjadilah 
pertengkaran mulut yang berujung kekerasan fisik sehingga, isteri membuat laporan di PPA Polres Bone.

Dari hasil laporan tdrsebut kemudikan melakukan mediasi terhadap kedua pihak namun, tidak membuahi hasil karena keegoisan masing-masing sehingga palapor melanjutkan laporannya di PPA Polres Bone. Faktor utama penyebabnya adalah masalah ekonomi dan mayoritas pelakunya adalah suami dari korban. Menurut pengamatan penulis pendapatan suami atau gaji bulanan yang sering mengakibatkan terjadinya kekerasan fisik dimana suami yang pekerjaan nya tidak menetap dan di tambah harga sembako yang kian hari makin meningkat harganya. Selain dari itu biaya pendidikan anak juga mengkibatkan faktor pertengkaran, karena pada umumnya laporan yang masuk mengeluhkan terkait dengan biaya kebutuhan anak dan pendidikan.

Namun kasus KDRT merupakan delik aduan Bahwa yang dimaksud delik aduan adalah korban KDRT yang harus melaporkan tindak pidana yang dilakukan oleh pelaku kekerasan fisik/psikis terhadap istri tanpa adanya laporan, pihak kepolisian tidak dapat memproses tindak pidana ini. Akibat dari delik aduan ini, korban dapat sewaktu-waktu dapat mencabut laporan di kepolisian. Ketentuan ini dapat mengakibatkan kasus-kasus KDRT tidak pernah selesai atau pelakunya tidak dihukum sesuai dengan perbuatannya. Ketika kita berbicara mengenai keluarga, berarti bicara mengenai isteri, suami dan juga anak, namun Tidaklah mudah untuk membentuk keluarga yang damai, aman, bahagia, dan sejahtera. Diperlukan pengorbanan serta tanggungjawab dari masing-masing pihak dalam menjalankan peran dalam keluarga. Rasa cinta, hormat, setia, saling menghargai dan lain sebagainya merupakan hal wajib yang perlu dibina baik suami maupun istri. Dengan mengetahui dan memahami hak dan kewajiban suami istri yang baik diharapkan dapat mempermudah kehidupan keluarga berdasarkan ajaran agama dan hukum yang berlaku.

\section{KESIMPULAN DAN SARAN}

Hasil penelitian dan pembahasan dapat disimpulkan bahwa kasus kekerasan dalam rumah tangga yang terjadi di Polrestabes Bone sudah dilaksanakan sesuai prosedur yang berlaku karena dimana kepolisian melakukan gelar perkara, dan apabila cukup bukti ditingkatkan ketahap penyidikan, membuat berita acara pemeriksaan (BAP), dengan memeriksa saksi-saksi, memeriksa keterangan ahli, memeriksa surat, dan menetapkan tersangka. Faktor penyebab terjadinya kekerasan dalam rumah tangga di Polres Bone, yaitu: pengaruh faktor ekonomi, faktor keturunan, atau tidak punya anak, serta faktor kesetiaan diantara suami isteri. Faktor-faktor ini lah yang menimbulkan terjadinya gejolak dalam rumah tangga yang mendorong adanya perceraian dalam rumah tangga.

Adapun saran dalam penelitian ini agar Pemerintah setempat giat melakasanakan sosialisasi dan penyuluhan hukum terkait dengan tindak pidana kekerasan dalam rumah tangga yang melibatkan unsur dari Pihak Kepolisian, Dinas pemberdayaan perempuan dan anak, dan Dinas sosial. Agar masyarakat lebih dapat memahami. Pentingnya komunikasi dan saling menghargai antara suami dan istri serta tidak lupa peranan masing - masing. Sehingga kekerasan dalam rumah tangga tidak terjadi, karena hal tersebut pula membuat awal terjadinya kekerasan dalam rumah tangga.

\section{DAFTAR PUSTAKA}

Adami Chazawi. 2014. Pelajaran Hukum Pidana Bagian 1. PT Rajagrafindo Persada. Jakarta.

Andi Sofyan dan Nur Azisa. 2016. Hukum Pidana. Pustaka Pena Press. Makassar.

Bambang Waluyo. 2011. Viktimologi Prtlindungan Korban \& Saksi. Sinar Grafika. Jakarta

Chazawi, Adami. 2013. Kejahatan Terhadap Tubuh dan Nyawa. Jakarta: Rajawali Pers. Departemen Pendidikan Nasional.

Dedi Risfandi. 2014. Perlindungan Hukum Terhadap Perempuan Korban Tindak Pidana Kekerasan Fisik Dalam Lingkup Rumah Tangga Di Kota Makassar. Skripsi. Sarjana Hukum. Fakultas Hukum Universitas Hasanuddin. Makassar.

Dwi Narwoko dan Bagong Suyanto. 2007. Sosiologi: Teks Pengantar dan Terapan. Jakarta: Kencana.

Dharmono, S. dan Diatri H. 2008. Kekerasan dalam Rumah Tangga dan guru besar dampaknya terhadap Kesehatan Jiwa. Jakarta: balai penerbit FK-UI.

Edi, Cahyo \& Iswahyudi, Didik. Kekerasan dalam Rumah Tangga (KDRT) Bertentangan dengan Hak Asasi Manusia (HAM) Di Wilayah Kelurahan Turen. (http://ejournal.unikama.ac.id/index.php/jrnspirasi/article /viewFile/693/442, Diakses 5 Juli 2017)

Gosita, Arif. 1993. Masalah Korban Kejahatan, Edisi Kedua. Jakarta: Akademika Pressindo.

Gultom, Maidin. 2014. Perlindungan Hukum terhadap Anak dan Perempuan. Bandung: Refika Aditama

Harkrisnowo, Harkristuti. 2000. Hukum Pidana dan Kekerasan terhadap Perempuan. Jakarta: KKCWPKWJ UI.

Hamzah, Risma, Abdul Salam Siku, and Yulia Hasan. "Efektivitas Fungsi Pembimbing Kemasyarakatan Dalam Pendampingan Anak Yang Berhadapan Dengan Hukum Pada Proses Diversi Tindak Pidana Pencurian." Indonesian Journal of Legality of Law 3.1 (2020): 1825. https://doi.org/10.35965/ijlf.v3i1.586. Diakses tanggal 13.juli 2021

Hasan, M. I. 2002. Pokok-pokok Materi Metodologi Penelitian dan Aplikasinya. Bogor: Ghalia Indonesia.

Iin Wahyu Priani. 2012. Tinjauan Yuridis Terhadap Tindak Pidana Kekerasan Fisik Dalam Lingkup Rumah Tangga. Skripsi. Sarjana Hukum. Fakultas Hukum Universitas Hasanuddin. Makassar.

Leden Marpaung . 2012. Asas-Teori-Praktik Hukum Pidana. Sinar Grafika. Jakarta.

Martha, Aroma Elmina. 2015. Hukum KDRT. Yogyakarta: Aswaja Pressindo.

Marbun, B.N. 2006. Kamus Hukum Indonesia. Jakarta: Pustaka Sinar Harapan.

Moerti Hadiati. 2011. Kekerasan Dalam Rumah Tangga Dalam Prespektif Yuridis-Viktimologis. Sinar Grafika. Jakarta.

Maya Indah. 2014. Perlindungan Korban Suatu Prespektif Viktimologi dan Kriminologi. Kencana Prenadamedia Group. Jakarta

Maidin Gultom. 2014. Perlindungan Hukum Terhadap Anak dan Perempuan. PT Refika Aditama. Bandung.

Sugiyono. 2010. Memahami Penelitian Kualitatif. Bandung: Alfabeta.

Wirjono Prodjodikoro. 2011. Asas-Asas Hukum Pidana Di Indonesia. PT Refika Aditama. Bandung. Skripsi 
Widianto, Asep, Marwan Mas, and Yulia A. Hasan. "Efektivitas Perlindungan Anak Yang Melakukan Pencurian Dengan Kekerasan Di Kota Makassar (Studi Kasus Pada Polrestabes Makassar)." Indonesian Journal of Legality of Law 2.1 (2019): 38-44. https://doi.org/10.35965/ijlf.v2i1.177. Diakses pada tanggal 13 juli 2021.

Undang-Undang Nomor 1 Tahun 1974 tentang Perkawinan. Undang-Undang Nomor 23 Tahun 2004 tentang Penghapusan Kekerasan Dalam Rumah Tangga. Undang-Undang Nomor 31 Tahun 2014 tentang Perubahan atas UndangUndang Nomor 13 Tahun 2006 tentang Perlindungan Saksi dan Korban. UndangUndang Nomor 8 Tahun 1981 tentang Kitab Undangundang Hukum Acara Pidana. 